INDONESIA ACCOUNTING JOURNAL

VOLUME 2, NUMBER 2, YEAR 2020

${ }^{1}$ Corresponding author

Jurusan Akuntansi

Fakultas Ekonomi dan Bisnis

Universitas Sam Ratulangi

Jl. Kampus UNSRAT

Manado, Indonesia, 95115

E-mail: flixiona@gmail.com

${ }^{2,3}$ Jurusan Akuntansi

Fakultas Ekonomi dan Bisnis

Universitas Sam Ratulangi

Jl. Kampus UNSRAT

Manado, Indonesia, 95115

Article info:

Received 28 January 2020

Accepted 28 January 2020

Available online 28 January 2020

Keywords: analysis; tax; cost of goods sold

JEL Classification: $\mathrm{H}_{25}$, M41

DOI: http://doi.org/10.3240o/iaj.27775

\section{Analisis penerapan pajak restoran pada penjualan (Studi kasus Rumah Makan Geprek Jo Manada)。}

\author{
Dennis Piere Maramis ${ }^{1}$ \\ Ventje Ilat ${ }^{2}$ \\ Lidia M. Mawikere ${ }^{3}$
}

\begin{abstract}
The tax is a compulsory contribution of citizens to the government and is imposed on the public based on the provisions of applicable law. Consideration of the cost of goods sold for a product and how to calculate restaurant taxes is one of the crucial things in a restaurant business, in an era where UMKM have been increasingly prioritized by the government to build a stronger national economy, pricing and tax calculation for a product is very important by the business of the people or companies. One type of tax whose potential is growing along with the increase in the leisure or tourism business is restaurant tax. This study aims to determine the application of restaurant taxes on the main cost of selling at Geprek Jo Restaurant. The analytical method used in this thesis research is a qualitative descriptive method. Geprek Jo Restaurant is a restaurant with a mainstay menu of Chicken and Tuna in Geprek with special chili seasonings Geprek Jo Restaurant which was established in September 2018. Calculation of cost of goods sold consists of raw material costs, direct labor costs and costs restaurant overhead, and calculate initial inventory, ending inventory, purchases and production in progress. The results of the calculation of cost of goods sold which require inventory elements get a smaller figure than the selling price of the product after classification. Then there are still benefits for the company. The results obtained that the cost of goods sold at Jo Geprek Restaurant is influenced by restaurant taxes.
\end{abstract}

\section{Pendahuluan}

Pajak adalah iuran bagi setiap warga negara kepada pemerintah berdasarkan undang-undang yang ada. Salah satu pajak yang memiliki potensi semakin berkembang pesat saat ini dengan meningkatnya bisnis pariwisata adalah pajak restoran. Menurut Undang-Undang Republik Indonesia Nomor 28 Tahun 2009 Tentang Pajak Daerah dan Retribusi Daerah, Pajak Restoran adalah pajak atas pelayanan yang disediakan oleh restoran.

Restoran adalah fasilitas penyedia makanan dan minuman yang dipungut bayaran, yang mencakup rumah makan, kafetaria, kantin, warung, bar, dan sejenisnya termasuk jasa boga/katering, pajak restoran dipungut atas pelayanan yang disediakan oleh restoran. Apabila setiap daerah bisa mengusahakan pendapatan atas pajak dan retribusi daerah secara maksimal, hingga daerah akan mampu memajukan setiap bidang-bidang berkaitan langsung dengan pertumbuhan ekonomi.

\section{Tinjauan pustaka}

Menurut Mulyadi (2015:7), akuntansi biaya merupakan serangkaian proses pencatatan, penggolongan, peringkasan, dan penyajian biaya, pembuatan dan penjualan produk dan jasa, dengan cara-cara tertentu, serta penafsiran terhadapnya. Lebih lanjut, Mulyadi (2015:7) menjelaskan bahwa akuntansi biaya berfungsi untuk menentukan biaya dalam penghitungan harga pokok produksi yang akan dilaporkan dalam laporan keuangan. Mulyadi (2015:7) menjelaskan bahwa akuntansi biaya 
menyediakan data biaya dalam penetapan harga pokok penjualan.

Menurut Undang-Undang Ketentuan Umum dan Tata Cara Perpajakan Tahun 2007, pajak adalah kontribusi wajib kepada daerah yang terutang oleh orang pribadi atau badan yang bersifat memaksa berdasarkan Undang-Undang, dengan tidak mendapatkan imbalan secara langsung dan digunakan untuk keperluan daerah bagi sebesar-besarnya kemakmuran rakyat. Wajib pajak adalah orang pribadi atau badan, meliputi pembayar pajak, dan pemungut pajak, yang mempunyai hak dan kewajiban perpajakan sesuai dengan ketentuan peraturan perundang-undangan perpajakan. Pajak adalah iuran rakyat kepada Negara yang dapat dipaksakan tanpa jasa timbal langsung (Mardiasmo, 2016:1). Definisi pajak adalah prestasi kepada pemerintah yang terutang, dan dapat dipaksakan dengan maksud untuk membiayai pengeluaran pemerintah (Sukrisno, 2014:6). Ada 2 (dua) fungsi pajak (Mardiasmo, 2016:4) yaitu:

1. Fungsi anggaran (budgetair). Pajak sebagai sumber dana bagi pemerintah untuk membiayai pengeluaran-pengeluarannya.

2. Fungsi mengatur (regulerend). Pajak sebagai alat untuk mengatur atau melaksanakan kebijakan pemerintah dalam bidang sosial dan ekonomi.

Kepatuhan Wajib Pajak (WP) atas kewajiban perpajakan merupakan salah satu ukuran kinerja wajib pajak dibawah pengawasan Direktorat Jenderal Pajak (Pandiangan, 2014:245). Berdasarkan Undang-Undang Republik Indonesia Nomor 16 Tahun 2009 Tentang Penetapan Peraturan Pemerintah Pengganti UndangUndang Nomor 5 Tahun 2008 Tentang Perubahan Keempat Atas Undang-Undang Nomor 6 Tahun 1983 Tentang Ketentuan Umum dan Tata Cara Perpajakan Menjadi Undang-Undang, bahwa Wajib Pajak adalah orang pribadi atau badan, meliputi pembayar pajak, pemotong pajak, dan pemungut pajak, yang mempunyai hak dan kewajiban perpajakan sesuai dengan ketentuan peraturan perundang-undangan perpajakan.

Berdasarkan Undang-Undang Nomor 8 Tahun 1983 bahwa Wajib Pajak yang telah memenuhi persyaratan subjektif dan objektif sesuai dengan ketentuan perundangundangan perpajakan wajib mendaftarkan diri pada Kantor Direktorat Jenderal Pajak yang wilayah kerjanya meliputi tempat tinggal atau tempat kedudukan Wajib Pajak dan kepadanya diberikan Nomor Pokok Wajib Pajak. Berdasarkan Undang-Undang Nomor 8 Tahun 1983 bahwa setiap Wajib Pajak sebagai Pengusaha yang dikenai pajak wajib melaporkan usahanya pada Kantor Direktorat Jenderal Pajak yang wilayah kerjanya meliputi tempat tinggal atau tempat kedudukan Pengusaha, dan tempat kegiatan usaha dilakukan untuk dikukuhkan menjadi Pengusaha Kena Pajak. Menurut Mardiasmo (2016:5), terdapat 5 (lima) teori yang mendukung pemungutan pajak yaitu:

1. Teori asuransi. Negara melindungi keselamatan jiwa, harta benda, dan hakhak rakyatnya. Oleh karena itu rakyat harus membayar pajak yang diibaratkan sebagai suatu premi asuransi karena memperoleh jaminan perlindungan tersebut.

2. Teori kepentingan. Pembagian beban pajak kepada rakyat didasarkan pada kepentingan (misalnya perlindungan) masing-masing orang. Semakin besar kepentingan seseorang terhadap Negara, makin tinggi pajak yang harus dibayar.

3. Teori daya pikul. Beban pajak untuk semua orang harus sama beratnya, artinya pajak harus dibayar sesuai dengan daya pikul masing-masing orang. Untuk mengukur daya pikul dapat digunakan 2 (dua) pendekatan yaitu: (a) unsur objektif, dengan melihat besarnya penghasilan atau kekayaan yang dimiliki seseorang; dan (b) unsur subjektif, dengan memperhatikan besarnya kebutuhan materiil yang harus dipenuhi.

4. Teori bakti. Dasar keadilan pemungutan pajak terletak pada hubungan rakyat dengan negaranya. Sebagai warga Negara yang berbakti, rakyat harus selalu menyadari bahwa pembayaran pajak adalah sebagai suatu kewajiban.

5. Teori asas daya beli. Dasar keadilan terletak pada akibat pemungutan pajak. Maksudnya memungut pajak berarti 
menarik daya beli dari rumah tangga masyarakat untuk rumah tangga Negara. Selanjutnya Negara akan menyalurkannya kembali ke masyarakat. Dengan demikian kepentingan seluruh masyarakat lebih diutamakan.

Menurut Undang-Undang Republik Indonesia Nomor 28 Tahun 2009 tentang Pajak Daerah dan Retribusi Daerah, Pajak Restoran adalah pajak atas pelayanan yang disediakan oleh restoran. Harga pokok penjualan merupakan salah satu unsur dari laporan laba-rugi suatu entitas dagang. Apabila entitas akan menyusun laporan keuangan khususnya laporan laba-rugi maka harus dilakukan perhitungan harga pokok penjualan yang terjadi dalam periode berjalan. Harga pokok penjualan terdiri atas beberapa biaya, yaitu:

a. Persediaan. Karena harga pokok penjualan merupakan bagian dari produksi, maka persediaan merupakan salah satu komponennya. Untuk menghitung inventory pada harga pokok penjualan, maka persediaan awal ditambahkan dengan pembelian barang dagangan saat periode berjalan dan dikurangi dengan persediaan akhir atau sisa persediaan. Jika perusahaan bergerak di bidang manufaktur, maka persediaan barang terdiri dari persediaan bahan baku, persediaan barang dalam proses dan persediaan barang jadi. Sementara, jika perusahaan bergerak di bidang usaha dagang, maka besarnya persediaan barang yang terjual adalah persediaan barang jadi. Untuk menghitung persediaan harga pokok penjualan: (1) persediaan awal, merupakan persediaan yang berasal dari periode sebelumnya; (2) pembelian, yaitu pembelian bersih; (3) harga pokok produksi, jika perusahaan bergerak dibidang manufaktur; dan (4) persediaan akhir, merupakan persediaan akhir yang tersisa pada akhir periode.

b. Tenaga kerja langsung. Tenaga kerja langsung juga merupakan komponen biaya untuk menghitung cost of good sold. Hal ini karena biaya tenaga kerja langsung terlibat dalam proses produksi produk atau jasa. Untuk menghitung biaya atau beban tenaga kerja langsung, dapat melihat jumlah upah atau gaji yang dikeluarkan perusahaan. Jumlah biaya tenaga kerja langsung juga dipengaruhi upah harian yang dihitung dengan tarif per jam atau target banyaknya unit yang dapat dihasilkan.

c. Biaya overhead. Komponen cost of good soldselanjutnya yakni biaya overbead. Biaya overhead merupakan biaya yang muncul selain dari biaya inventory dan biaya tenaga kerja langsung. Biaya overhead dapat dibedakan menjadi beberapa jenis seperti berdasarkan skala usaha, jenis usaha, sumber daya yang digunakan dan lain sebagainya. Biaya overbead juga biasanya disebut dengan biaya tidak langsung. Sebagai contoh beberapa biaya yang termasuk dalam biaya overhead, sebagai berikut: (1) Biaya sewa; (2) Depresiasi peralatan; (3) Biaya listrik, air, telepon, dan lainnya; dan (4) Biaya gudang, dan lain sebagainya.Menghitung cost of good sold adalah hal yang penting karena perusahaan akan mendapatkan banyak manfaat, diantaranya seperti:

a. Menentukan harga jual. Umumnya pelaku usaha mengandalkan biaya produksi sebagai patokan dalam menentukan harga jual. Namun jika hanya mengandalkan biaya produksi atau kekuatan tawar menawar maka resiko kerugian akan meningkat lebih besar. Untuk mengatasinya, perusahaan dapat mempertimbangkan dan menentukan harga jual produknya melalui perhitungan cost of good sold sehingga harga jual yang dihasilkan tepat.

b. Menghitung laba rugi. Dengan melakukan perhitungan cost of good sold atau harga pokok penjualan yang akurat, maka dapat dinilai laba atau rugi yang akan diterima perusahaan. Hal ini dapat diketahui jika harga jual lebih besar dari cost of good sold maka perusahaan akan mendapatkan laba, sedangkan jika harga jual lebih 
rendah dari cost of good sold maka pihak tersebut akan mengalami kerugian.

Panjaitan dan Natalia (2018) menyatakan bahwa pajak restoran dan biaya sewa gedung secara parsial berpengaruh secara signifikan terhadap penetapan harga jual pada restoran di Kota Batam. Rosandi dan Purba (2015) menyatakan bahwa nilai koefisien korelasi antara harga pokok penjualan terhadap tingkat pengembalian modal (return on equity) tidak saling mempengaruhi selama periode 2005 sampai dengan 2014. Menurut Indra (2019), penentuan harga pokok penjualan sesuai konsep akuntansi biaya berdampak pada penentuan harga jual dan laba rugi perusahaan. Saputra et al. (2017) menyatakan bahwa harga pokok penjualan yang lebih kecil dari harga jual produk mengakibatkan keuntungan bagi perusahaan.

Wuryansari (2016) mengemukakan bahwa perhitungan harga pokok produksi susu cup menurut perusahaan memiliki perbedaan dengan perhitungan harga pokok produksi yang menggunakan metode full costing yang disebabkan karena perusahaan tidak memasukkan biaya depresiasi gedung danmesin ke dalam perhitungan harga pokok produksi. Menurut Sululing dan Asharudin (2016), perhitungan harga pokok penjualan dari tahun 2013 sampai dengan 2014 dapat diketahui bahwa laba yang diperoleh belum optimal karena target penjualan yang ditetapkan setiap tahunnya belum tercapai. Menurut Irasanti (2019), Harga Pokok Produksi (HPP) ternak ayam ras pedaging pola kemitraan lebih rendah dibandingkan dengan non kemitraan. HPP pola kemitraan dan nonkemitraan dihitung dengan metode full costing.

\section{Metode penelitian}

Jenis penelitian yang digunakan adalah deskriptif kualitatif yang merupakan sebuah metode penelitian yang memanfaatkan data kualitatif dan dijabarkan secara deskriptif. Jenis penelitian deskriptif kualitatif menampilkan hasil data apa adanya tanpa proses manipulasi atau perlakuan lain.Penelitian ini bertempat di Rumah Makan Ayam Geprek Jo Bethesda yang berlokasi di Jl. Bethesda, Sario, Manado depan Gedung Keuangan Negara. Penelitian ini menggunakan data kualitatif yang merupakan data yang disajikan dalam bentuk uraian, seperti gambaran umum perusahaan.

Dalam penelitian ini adalah data primer yang diperoleh langsung didapatkan dari pemilik rumah makan Geprek Jo. Dalam penelitian ini, metode pengumpulan data yang digunakan adalah wawancara, observasi dan dokumentasi. Proses analisis adalah memahami seluruh informasi yang terdapat pada suatu kasus, menganalisis situasi untuk mengetahui isu yang sedang terjadi, dan memutuskan tindakan yang harus segera dilakukan untuk memecahkan masalah. Teknik analisis data yang digunakan dalam penelitian ini yaitu analisis deskriptif. Menurut Sugiyono (2017:147), analisis deskriptif adalah cara mendeskripsikan atau menggambarkan data yang telah terkumpul.

\section{Hasil penelitian dan pembahasan}

\section{Hasil penelitian}

Penelitian ini tidak memperoleh data pembelian bahan baku per tahun ataupun triwulan di karenakan pencatatan data pembelian bahan baku yang digunakan oleh Rumah Makan Geprek Jo tidak dilakukan. Oleh karena itu, penenlitian ini hanya menggunakan data pembelian selama satu bulan saja yaitu bulan September 2018 dan dengan mewawancarai Bapak Joshua untuk setiap data yang diperlukan. Bahan baku yang digunakan adalah bahan baku pilihan yang berkualitas baik yang dibeli di pasar swalayan Manado dengan harga yang terjangkau dan kualitas yang bagus. Sebagaimana yang sudah disampaikan oleh Bapak Joshua, "Bahan baku yang digunakan dalam proses produksi Rumah Makan Geprek Jo, kita menggunakan bahan baku yang berkualitas seperti baban baku ayam daging yang dibeli di Jumbo Mart karena melihat harga murah serta berkualitas, ikan tuna dibeli di Lotte Mart karena harga yang terjangkau juga dan kualitasnya impor, dan rempah-rempah yang dibeli di Freshmart" (Wawancara tanggal 20 Desember 2019 dengan informan utama di rumah makan Geprek. Jo yaitu Bapak Joshua sebagai owner dari rumah makan 
Geprek Jo). Penghitungan harga pokok penjualan yang terdiri dari biaya bahan baku, biaya tenaga kerja langsung dan biaya overhead rumah makan, dan menghitung persediaan awal, persediaan akhir, pembelian serta produksi dalam proses.

\section{Pembahasan}

Berdasarkan hasil wawancara dengan pemilik Rumah Makan Geprek Jo, selama satu bulan rumah makan tersebut menerima pendapatan dari hasil penjualan makanan dan minuman yang dimiliki sebesar Rp. 45.000.000. Maka besaran pajak rumah makan yang harus dibayarkan oleh rumah makan Geprek Jo dapat dilihat dari perhitungan pajak restoran dibawah ini:

Pajak Restoran = Dasar Pengenaan Pajak $\times$ Tarif Pajak

Dasar Pengenaan Pajak adalah pendapatan

yang didapat dari konsumen

$=$ Rp. $45.000 .000 \times 10 \%$

$=$ Rp. 4.500 .000

Oleh karena itu, Rumah Makan Geprek Jo menetapkan pajak $10 \%$ atau service charge kepada pelanggan untuk memastikan restoran tetap mampu membayar pajak. (Wawancara tanggal 20 Desember 2019 dengan pemilik Rumah Makan Geprek Jo Bapak Joshua).

\section{Kesimpulan dan saran \\ Kesimpulan}

Berdasarkan hasil penelitian dan pembahasan dapat disimpulkan sebagai berikut, bahwa hasil dari perhitungan harga pokok penjualan yang membutuhkan unsurunsur persediaan, mendapatkan angka yang lebih kecil dari harga jual produk setelah dilakukannya pengklasifikasian. Maka masih didapatkan keuntungan bagi perusahaan Harga pokok penjualan Rumah Makan Geprek Jo mengalami kenaikan harga sehingga mengalami rendahnya laba sehingga pajaknya rendah.

\section{Saran}

Setelah dikemukakan kesimpulan diatas, maka saran yang diajukan sebgagai berikut, Rumah Makan Geprek Jo agar dapat menjalankan standar operasional rumah makan agar dapat mengurangi setiap biayabiaya yang keluar juga dapat meminimalkan penggunaan biaya overhead yang berdampak pada harga jual yang nantinya berujung pada pendapatan laba.

\section{Daftar pustaka}

Irasanti, D. (2019). Analisis harga pokok produksi dan keuntungan usaha ternak ayam ras pedaging. Skripsi.

http://digilib.unila.ac.id/56513/3/SKRIPSI $\% 20$ TANPA $\% 20 B A B \% 20 P E M B A H A S A N . p d f$

Indra. (2019). Analisis penentuan harga pokok penjualan pada perusahaan kecap UD. Hasil Bumi Sumenep. http://repository.wiraraja.ac.id/147/

Skripsi.

Mardiasmo, (2016). Perpajakan. Yogyakarta: Penerbit Andi.

Mulyadi. (2015). Akuntansi biaya, Edisi 5. Yogyakarta: Sekolah Tinggi Ilmu Manajemen YKPN.

Pandiangan, L. (2014). Administrasi perpajakan. Jakarta: Penerbit Erlangga.

Panjaitan, M., \& Natalia, E. Y. (2017). Pengaruh pajak restoran dan biaya sewa gedung terhadap penetapan harga jual pada restoran di Kota Batam. Jurnal Akuntansi Barelang, 1(2), 116-128. http:// ejournal.upbatam.ac.id/index.php/jab/ar ticle/view/175

Rosandi, A., \& Purba, J. H. V. (2015). Analisis pengaruh harga pokok penjualan dan biaya operasional terhadap tingkat pengembalian modal studi kasus pada PT. Mayora Indah Tbk dan PT. Indofood Sukses Makmur Tbk. Accounting Symposium, At STIE Kesatuan. https://www.researchgate.net/publication/3291 10625_ANALISIS_PENGARUH_HARGA_P OKOK_PENJUALAN_DAN_BIAYA_OPER ASIONAL_TERHADAP_TINGKAT_PENG EMBALIAN_MODAL

Saputra, H., Rosyafah, S., \& Susanti, W. (2017). Analisa harga pokok penjualan untuk menentukan pendapatan laba (Studi kasus rumah makan cepat saji KFC Store Pondok Tjandra Surabaya). Equity, 3(2), 259-271. http://fe.ubhara.ac.id/ojs/index.php/equity/arti cle/view/428

Sugiyono. (2017). Metode Penelitian Kuantitatif, Kualitatif, dan R\&D. Bandung : Alfabeta.

Sululing, S., \& Asharudin, D. (2016). Analisis harga pokok penjualan pada laba di Apotik Kimia Farma No. 66 Luwuk. Jurnal Ekonomi, 21(1), 23-42. http://dx.doi.org/10.24912/je.v21i1.380

Sukrisno, A. (2014). Akuntansi perpajakan, Edisi 3. Jakarta : Salemba Empat.

Undang-Undang Nomor 28 Tahun 2007 tentang Ketentuan Umum dan Tata Cara Perpajakan.

Undang-Undang Nomor 8 Tahun 1983 tentang Pajak Pertambahan Nilai.

Undang-Undang Republik Indonesia Nomor 16 Tahun 2009 tentang Penetapan Peraturan UndangUndang Republik Indonesia Nomor 28 Tahun 2009 tentang Pajak Daerah dan Retribusi Daerah.

Wuryansari, A. (2016). Analisis perhitungan harga pokok produksi dengan menggunakan metode full costing sebagai dasar penentuan harga jual (Studi kasus di Peternakan Seraphine Yogyakarta). https://repository.usd.ac.id/6963/2/112114129 _full.pdf 